\title{
Chapter 79 \\ Engineering the Emirates: \\ The Evolution of a New Environment
}

\author{
Pernilla Ouis
}

\subsection{Introducing the Riddle}

Few places on this earth have shown such a remarkable development in a short time span as the United Arab Emirates (UAE). Today the country is the leading site for the latest ultramodern architecture and revolutionary landscaping applying the most up-to-date technology. An index of this development is that over a third of the world's cranes are found in the emirates, a fact often proudly mentioned in their public discourse. A number of megaengineering projects are implemented at the moment. Absolutely nothing seems impossible here! It is a paradise for enthusiastic developers and investors, and for experts such as engineers and architects seeking challenges.

As a human ecologist I am interested in human-environmental relationships. In my thesis I completed a study in the UAE on the theme that is best expressed in an easy slogan as "modernizing nature - naturalizing modernity" (Ouis, 2002a). Based on this thesis and the most recent megaengineering projects in the UAE, the riddle in this paper is: How is it possible that the mega-projects in the UAE are presented as environment friendly in the public discourse? This question is based on the assumption that such megaengineering projects are somehow problematic for the environment, a point to which I will return later in this paper. First, I will first in give a brief introduction to the UAE and some of its most spectacular megaengineering endeavors. It has been necessary to rely on Internet as a source, in part because so few books provide accounts of the most recent development. My objective is not to provide only impressive facts, but rather to show a smorgasbord of these projects to illuminate their scope. By giving examples from the discourse regarding these projects, I will problematize the notion of their benefits for the environment. Finally, I analyze this discourse based on theories about ecological modernization.

\footnotetext{
P. Ouis $(\bowtie)$

Faculty of Health and Society, Malmö University, Malmö, Sweden

e-mail: pernilla.ouis@mah.se
} 


\subsubsection{The United Arab Emirates}

The UAE is a federation established in 1971 of seven sheikhdoms or emirates on the Arab coast of the Persian Gulf. These emirates were former British protectorates. The capital is Abu Dhabi, which is also the name of the largest emirate that constitutes almost $87 \%$ of the country's territory (Heard-Bey, 1996: 11). Perhaps the most famous city (and name of a small emirate) is Dubai. The Emirati economy has been based on the export of fossil fuels since the early 1960s, but other forms of business and financial activities are rapidly growing in their importance to meet the post-oil era. Furthermore, the country has invested many resources in developing tourism as the primary source of income. The major motive behind the boom in building, landscaping and greening during the last couple decades is to attract foreign investors, business and tourists. However, another motive for constructing all the megaprojects might be: "Because they can." Unlike most developing countries, the Emirates have the financial means to carry out all these spectacular endeavors. On a cultural analysis level, the inferiority complex towards the West, with its roots in Orientalism, often inspire developing Arab countries to show that they are utterly modern in order to combat prejudices of Arab backwardness. Furthermore, and perhaps given less attention, is that these megaprojects are manifestations and legitimization of power in a somehow unstable political setting, for instance with threats from Islamists and democratic human rights movements. The projects can also be seen as articulation of the interior competition between the different emirates and other Arab oil states based on the traditional prestige society (i.e., the tribal kinship society) (Heard-Bey, 1997; Ouis, 2002a).

The UAE has an extreme physical environment: a naturally very hot climate, humid air, but little rainfall and little vegetation apart from the low scrubby desert and the traditional date palm plantations in the oases. The climate is arid subtropical climate with humidity exceeding $85 \%$, and on the coast up to $100 \%$ in summer (Long, 1996: 3). In winter the temperature range is between 17 and $20^{\circ} \mathrm{C}\left(63-68^{\circ} \mathrm{F}\right)$, while in July the shade temperature can reach $50^{\circ} \mathrm{C}\left(122^{\circ} \mathrm{F}\right)$ or more in the desert. Rainfall is very limited, infrequent and irregular, and droughts are also common. Abu Dhabi also includes parts of the large uninterrupted sand desert in interior of the Arabian peninsula: Rub' al-Khali, literally meaning "the empty quarter." The megaengineering projects are to some extent, in my interpretation, aiming at overcoming naturally harsh environmental conditions. Below, I will focus on some recent spectacular megaengineering projects, many which are still under construction: skyscrapers, ecological desert cities, winter sport facilities, artificial islands and various landscaping and greening projects.

\subsubsection{Towers Scraping the Sky and Ecological Desert Cities}

Skyscrapers are perhaps one of the most important manifestations of human power over nature and a prominent sign of modernity. The tallest buildings in the world today are all found in newly developed or developing countries and not in the West. 
The building of skyscrapers and high towers is a process that began on a large scale during the latest decade in the UAE. I will only mention a few of the newest ones. Burj al-Arab, meaning the "Tower of the Arabs," constructed 1994-1999 in Dubai, is with its $321 \mathrm{~m}(1,053 \mathrm{ft})$, the tallest hotel building in the world. It is marketed as the world's first and only "seven-star" hotel. It was built on an artificial island $280 \mathrm{~m}$ (919 ft) from the beach. The island took three years to build and the building of the hotel building another three years to complete. The hotel is built to resemble the sail of a dhow, a type of traditional boat from the Gulf. Two wings spread in a V to form a vast mast, while the space between them is enclosed in a massive atrium of $180 \mathrm{~m}$ $(891 \mathrm{ft})$ in height. One of the difficulties in the construction was to prevent large amounts of condensation or rain clouds from forming in the atrium. To lower the interior temperature, the building was cooled by one degree per day over a 6 months period (Jodidio, 2007: 42-49; Tom Wright, 2008).

The tallest building in the world is also found in Dubai: Burj Dubai (Burj Dubai was renamed into Burj Khalifa after it was opened in 2010) is presently the tallest human-made structure in the world since 7 April 2008. So far have only 160 floors have been completed, but the final height of the tower is officially being kept a secret due to competition from other buildings under construction or proposed. It has been suggested a final height of around $818 \mathrm{~m}(2684 \mathrm{ft})$ and the total number of floors is expected to be around 162 (Emaar Poperties, 2008). The design of the tower is made up of three elements grouped around a central core rising into a single spire, a form derived from local desert flowers (Jodidio, 2007: 178). Just like the dhow-like Burj Al-Arab, it should be noted how traditional elements are included in the modern design. The cultural sensitive balance between tradition and modernity is significant in the Arab Gulf States. The legitimization of power is grounded in history, tradition and culture as well as in modern development strategies (Ouis, $2002 b$ ). While the original inhabitants are only a small minority having Emirati citizenship in the country, the majority of the guestworkers come primarily from Asia. The building boom somehow presumes a growth both in economy and in population that supposedly must be met by immigration.

Burj Dubai competes with other projects as an expression of the interior regional rivalry. Few up-to-date books have been published on this theme (except for Jodidio, 2007), but a quick search on the Internet reveals that several buildings in the region are competing for the epithet "the tallest building in the world." For example, Murjan Tower in Manama, Bahrain, is expected to be $1,022 \mathrm{~m}(3,353 \mathrm{ft})$ in height with 200 floors (Emporis, 2008). But other high towers are planned; 1,001 m (3,284 $\mathrm{ft}$ ) Burj Mubarak al-Kabir is planned to be erected in Kuwait as part of a massive development project called Madinat al-Hareer. The project also includes an Olympic stadium, residences, hotels, and retail facilities. However, the project may require 25 years to complete (Luxury Launches, 2008). Even within Dubai, the tower is challenged by "The Tower", Al Burj, on a site near Dubai Marina. Speculation has suggested various heights between $750 \mathrm{~m}(2,461 \mathrm{ft})$ and 1,000 m (3,281 ft) (Burj Dubai Skyscraper, 2008). Finally, The Mile-High Tower, a recently announced skyscraper planned for Jeddah, Saudi Arabia, would be almost twice as tall as Burj Dubai, if completed as planned (SkyscraperPage Forum, 2008). 
Another tower that is not competing in height, but in genius engineering is the Da Vinci tower in Duabi. It is has been called many names: the Dynamic Architechture Building, the Rotating Skyscraper, and the Dynamic Tower. It will be $420 \mathrm{~m}$ (1,378 ft) with 80 floors, but the spectacular feature of the tower is that each floor can rotate independently of maximum $6 \mathrm{~m} / \mathrm{min}$, allowing full rotation in $90 \mathrm{~min}$. It is a prefabricated skyscraper built in a factory and not on site under construction at the moment. It is designed by the architect Florentine David Fisher, who says on the tower's official website:

The Dynamic Tower is environmentally friendly, with the ability to generate electricity for itself as well as other buildings nearby making it the first building designed to be selfpowered, it achieves this feat with wind turbines fitted between each rotating floor. An 80 -story building will have up to 79 wind turbines, making it a true green power plant.

He further states that: "From now on, buildings will have four dimensions, the fourth dimension is 'Time' to become part of architecture" (Dynamic Architecture, 2008).

Ecological awareness is definitely shown in the construction of these new buildings and cities. The "first positive energy building in the world" is under construction in Abu Dhabi. Sun panels will make the building produce more energy than it consumes. It will be the master-piece in Masdar, a new ecological city. The city has zero-waste and zero-carbon ambitions and $80 \%$ of its water will be recycled. The city will have a personal rapid transit system instead of cars. Designed by the dignitary Norman Foster, Masdar will be free from cars and run only by solar and wind energy. The project gained international attention as an ecological utopia and a testing ground for environmentally friendly technological solutions (The Masdar Initiative 2008). In another of the lesser developed emirate, a complete new eco city, the Ras al Khaimah's Gateway City, will be constructed from scratch in the desert for 150000 inhabitants. The city is calculated to be completed iin 2012 (Jodidio, 2007: 124-129; OMA, 2008).

\subsubsection{Engineering a New Environment: Ice, Snow, Islands and Creek Extension}

In the many publications on the UAE directed towards tourists, the country's winter sport facilities are always boosted about. "Isn't it amazing that skiing and skating can be done in the world's hottest climate?" This is the message. The massive use of energy for these many ice skating rinks and ski slopes is not a detail discussed in these publications. Ski Dubai, is a quite new indoor winter sport centre with 5 runs, the longest one is $400 \mathrm{~m}$ (1312 ft) long. The total area of the centre is $58,275 \mathrm{~km}^{2}$ $\left(22,500 \mathrm{mi}^{2}\right)$ covered with 6,000 tonnes $(6,614$ tons) of snow in total, 30-40 tonnes (33-44 tons) of new snow needs to be produced every night. Hence, the hot climate is not a limitation; nature can be altered.

Another quest to change the natural environment is the constructions of the many artificial islands. "The world" is a human constructed archipelago of 300 islands outside the coast of Dubai shaped as the world. It was constructed 2003-2008, $24 \mathrm{~h}$ a 
day, seven days a week. Each island can be bought for prices from \$US 10-45 million US. The most recent megaengineering of human-made islands are the three palm-shaped islands still under construction in Dubai. These tourist and residential complex shaped as palm trees topped with a crescent (breakwater) will add $520 \mathrm{~km}$ (1,705 mi) extra beach to Dubai. The smallest island, Palm Jumeriah has a size of 5 by $5 \mathrm{~km}$ (16.4 by $16.4 \mathrm{mi}$ ), has already been finalized (2001-2006). It has 17 fronds and has a surrounding crescent island as an $11 \mathrm{~km}$ (36 mi) long breakwater. Palm Jebel Ali, constructed 2002-2008, is 50\% larger than Palm Jumeirah and is expected to accommodate 1.7 million people by 2020 . Round the island houses on stilts form the poem by the ruler of Dubai saying: "Take wisdom only from the wise, not everyone who rides a horse is a jockey. It takes a man of vision to write on water, great men rise to great challenges" (Eikongraphia, 2008). This is yet another manifestation of power based on the twin pillars of tradition and modernity.

The largest island, Palm Deira will be eight times larger than palm Jumeirah once completed (under construction since 2004 with an estimated completion date in 2015). It will be the world's largest human-made island. Large amounts of sand and rock have been used in the construction: The first two islands used about 100 million $\mathrm{m}^{3}$ (3.53 billion $\mathrm{ft}^{3}$ ) of rock and sand; Palm Deira alone used 1 billion $\mathrm{m}^{3}$ ( 35.3 billion $\mathrm{ft}^{3}$ ) of rock and sand. The islands will have luxury hotels, villas, apartments, marinas, water theme parks, restaurants, shopping malls, sports facilities and health spas (Nakheel, 2008). The plan is to attract millions of tourists from the global elite.

A combination of landscaping, artificial islands and high towers are found in the human-made extension of Khor Dubai, the natural saltwater creek dividing the city of Dubai. The creek has recently been extended and redirected into the Gulf again, in total more than $12 \mathrm{~km}(39.4 \mathrm{mi})$, so that one part of the city, Bur Dubai, has become an island. This extension is part of the development of Business Bay that is planned to become a new financial megacenter in the world (Dubai Properties, 2008). Seven artificial islands will be created in connection to the creek. These are called The Lagoon and will just, as Business Bay, be developed into an explosion of skyscrapers inspired in their shape by candle lights, the Dubai Towers Dubai (Dubai Towers Dubai, 2008; Gulf News, 2008).

\subsubsection{Evolving a Whole New Environment: Greening the Emirates}

The UAE is famous for its achievements in greening the desert. This was a very special ambition of the late sheikh Zayed bin Sultan Al Nayhan (1918-2004), who has stated that: "They used to say, agriculture has no future, but with God's blessing and our determination, we have succeeded in transforming the desert into a green land." Figure 79.1 shows the cover of a publication of Sheikh Zayed as the leader who made the desert green. The greening ambitions are mostly implemented 


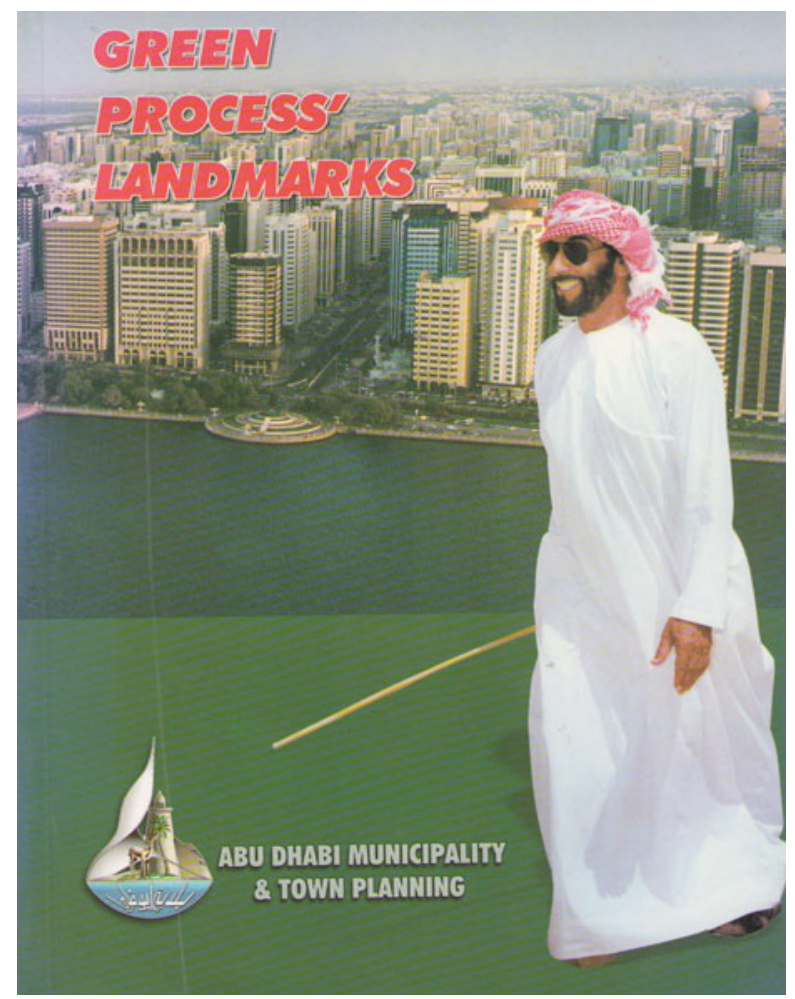

Fig. 79.1 Sheikh Zayed bin Sultan Al Nahyan (1918-2004) was the leading figure in the greening ambitions

in the emirate of Abu Dhabi, which covers $87 \%$ of the whole area of the UAE. The greening project discussed in the public discourse uses the phrase "rolling back the desert" which includes forestry (mostly plantations of date palm trees), agricultural development, parks, mangrove plantations on the coast, nature reserves and a global "green image." In 1980 forests covered $100 \mathrm{~km}^{2}\left(38.4 \mathrm{mi}^{2}\right)$ of Abu Dhabi, while in 2003 over $3,053 \mathrm{~km}^{2}\left(1,176 \mathrm{mi}^{2}\right)$ were forested. This is equal to an annual expansion of $26 \%$ (State of the Environment Abu Dhabi, 2008). One can recall the statement by Sheikh Mohammed bin Butti, chairman of Abu Dhabi municipality, to give a glimpse of the prevalent attitude towards forestry: "Plant more palm trees and still more palm trees. The desert is there before you. Confront the yellow invasion with the green invasion" (UAE Ministry of Information and Culture, 1993: 93-94). Forests are irrigated by groundwater, in total 607.3 million $\mathrm{m}^{3}\left(21.4\right.$ million $\left.\mathrm{ft}^{3}\right)$ per year; $80 \%$ of the total ground water in the emirate has already been used (State of the Environment Abu Dhabi, 2008). Desalinated water is increasingly being used, but the problem is that this type of water production requires huge amounts of energy. At the universities there are on-going experiments with salt tolerant plants which use sea water directly for irrigation (personal observation). 


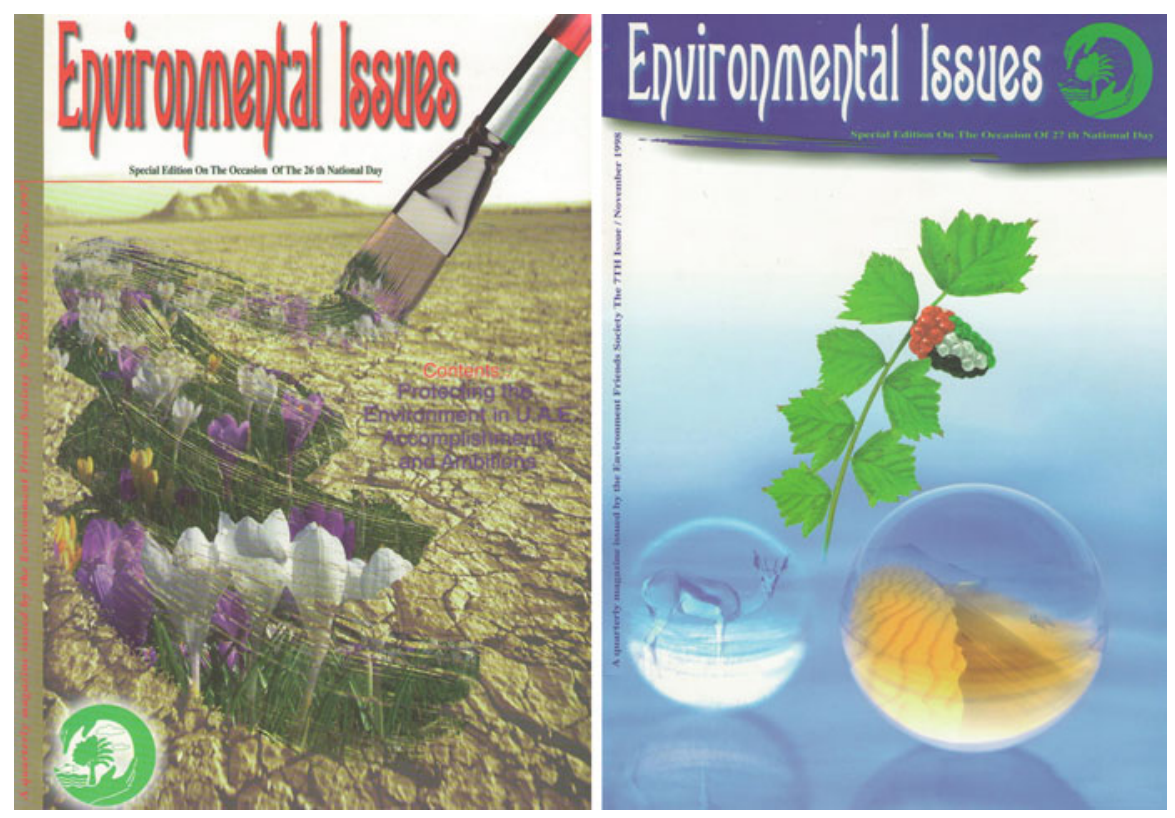

Fig. 79.2 The covers of two environmental magazines demonstrate the Emirati flag as a central feature in the greening efforts

The greening is perceived as part of the global battle to combat desertification. The UAE Ministry of Information and Culture (1995: 35) states in one of its publications that: "The process of desertification is not irreversible." Sheikh Zayed received during his lifetime (1995) an international award from UN Food and Agriculture Organization for his efforts to combat desertification. Hence the problem of desertification in poorer areas such as the Sahara in Africa serves to legitimize the greening projects in the UAE. Furthermore, in the Emirati public discourse the large green areas are presented in a way that they can create more rain and moderate the climate. This issue has been debated by scientists, saying that perhaps local microclimates can be affected, but not on a larger scale. The greening projects are seen as positive for the environment, not as problematic due to the high amount of water and fertilizers required. Forestry and greening are also framed in terms of nationalism and environmentalism. Figure 79.2 shows two covers from the Emirati environmental magazine Environmental Issues. Both pictures show the national flag, either as a brush brushing away the desert in one picture or as a colorful berry in the other, which has the central symbolic feature of greening the emirates.

\subsubsection{Environmental Problems with the Megaprojects}

The question that arises considering the enormous development of various megaengineering projects while at the same time maintaining an ecological image 
is: Is this development sustainable? My answer as a human ecologist is definitely "no." The UAE has serious environmental problems such as ground water depletion, large carbon dioxide emissions and the largest "ecological footprint" per capita in the world. It is a measure of the resource consumption translated into the amount of biologically productive land and sea area needed to regenerate (if possible) the resources a human population consumes and to absorb and render harmless the corresponding waste, given prevailing technology and current understanding. The ecological footprint per capita in the UAE is almost 12 ha (39.4 acres) per capita, a number that can be compared with what is often seen to the world's largest ecological sinner US with its 9.5 ha (31.1 acres) per capita. Global average is 2.2 ha (7.2 acres) per capita; the total supply of biocapacity is 1.8 ha (5.9 acres) per capita (Global Footprint Network 2008; data from 2003 presented in the 2006 edition). This fact has caused environmental concerns in the UAE. UAE Al Basama Al Beeiya, "the Ecological Footprint Initiative" was launched in October 2007 with the mission to produce an interim report to the Global Footprint Network for the 2008 calculations. The explanations for the large footprint were presented in the report in March 2008 which stated that the UAE has a higher population than previously considered, that the country is a regional re-export hub, and that it has little greenery to soak up carbon emissions (UAE Interact, 2008).

One of the most challenging environmental problems faced by the Emiratis is the water issue. Ground water depletion is a serious problem in this milieu. The water consumption today in the UAE is 3501 (370 quarts) per person per day in the UAE, that can be compared to USAs number of 4251 (449 quarts) per person per day. The greening projects demand large amounts of water, and the previous expansion rate of 3,000 new farms every year has been restricted. The water consumption rate is expected to be almost double in 2015. One of the problems is that desalinated water is available at very low price and subsidized by the government. The low price level does not motivate users to save water. (State of the Environment Abu Dhabi, 2008).

With the expected millions of new luxury tourists coming to the palm islands, the high towers, and the greening projects, the water issue becomes even more acute. But the energy issue also merits attention. It is argued that sun and wind energy will replace fossil fuels, but is this possible? How will the millions of tourists travel to the UAE if not by air? So far, there is no alternative for long distance travelling than air born fossil fuel based transportation. There are no alternatives developed yet within the UAE to replace car transportation, with the only exception being in Masdar. Public transport is today more or less non-existent. A large amount of energy consumed in the UAE is used for cooling indoor environments. Can solar panels cover that energy demand? A general issue that also must be raised is: Are the tourists' lifestyle sustainable? All the financial activities, consumerism and tourism are currently dependent on a fossil fuel based society, in addition to the fact that the export of fossil fuels remains the backbone of the economy. In my judgment no alternatives to the business-as-usual non-sustainable lifestyle are presented so far.

Leaving the lifestyles issues apart, we should also take a closer look at one of the mega-engineering projects: the artificial islands. Ironically, the rising sea levels from climate change can affect the islands as they run the risk of being flooded in 
a near future. The enormous dredging and redepositing of sand have made the sea water clouded with silt, causing organisms choked by the sediment particles. The construction of the islands damages the marine habitat, burying coral reefs, oyster beds and sea grass, threatening many marine species. The recent habitat loss of $35 \%$ in the Persian Gulf and its waters are increasing in salinity and temperature. The developer Nakheel claim that they will construct artificial reefs after the islands have been finalized. They also claim that the channels between the fronds of the palms are ideal habitat for seagrass. (Butler, 2005).

Environmental impact assessments are problematic, even though they are applied in the megaengineering projects. Nature is not so predictable, which sometimes can be positive since new species and habitats can arise in unexpected situations. However, it is important to ask which approach society has taken to deal with environmental problems. The UAE has chosen, along with the rest of the modernized world, the approach of ecological modernization that will be explained in detail below.

\subsubsection{Ecological Modernization in the UAE}

Ecological modernization, as defined by Hajer, 1995), is an environmental discourse which assumes that the existing political, economic and social institutions can take care of the environment. In the 1960s the environmentalist grassroots movement was considered a threat to project of modernity with its critique. However, the conflict between economic growth and ecological interests that characterized this early environmental movement has been reconciled within ecological modernization discourse from the late 1980s and onwards. In this discourse the conflict is presented as a "win-win" situation: economic growth is needed to attain the means for solving environmental problems, while a clean and sound environment is a precondition for economic expansion. Ecology and environmental concerns goes hand in hand, an idea manifested in the concept of "sustainable development." Critics have argued that in the new discourse it is rather the sustainability of economic growth, not of the environment, that is of concern. Within ecological modernization, modernity is not the cause of the environmental crisis, as presented in earlier environmentalism, but rather "Modernity is the solution." Environmental concerns are reduced to a management issue. Hence, ecology has become the masterframe of modernity, says sociologist Klaus Eder (1996). He elaborates that today we are in the post-Rio era experience a phase in which "the cultural normalization of environmental concerns and their integration with established patterns of ideological thought" emerges (Eder, 1996: 163). Figure 79.3 can be interpreted as an illustration of ecological modernization in the Gulf. The picture is from a cover of an environmental show and is illustrating a sick earth in a hospital bed surrounded by four male doctors curing the earth with modern technology.

I have identified the Emirati environmental public discourse as an expression of global ecological modernization (Ouis, 2002c). In the megaengineering projects the latest environmentally friendly technologies are being used, they are all preceded by 


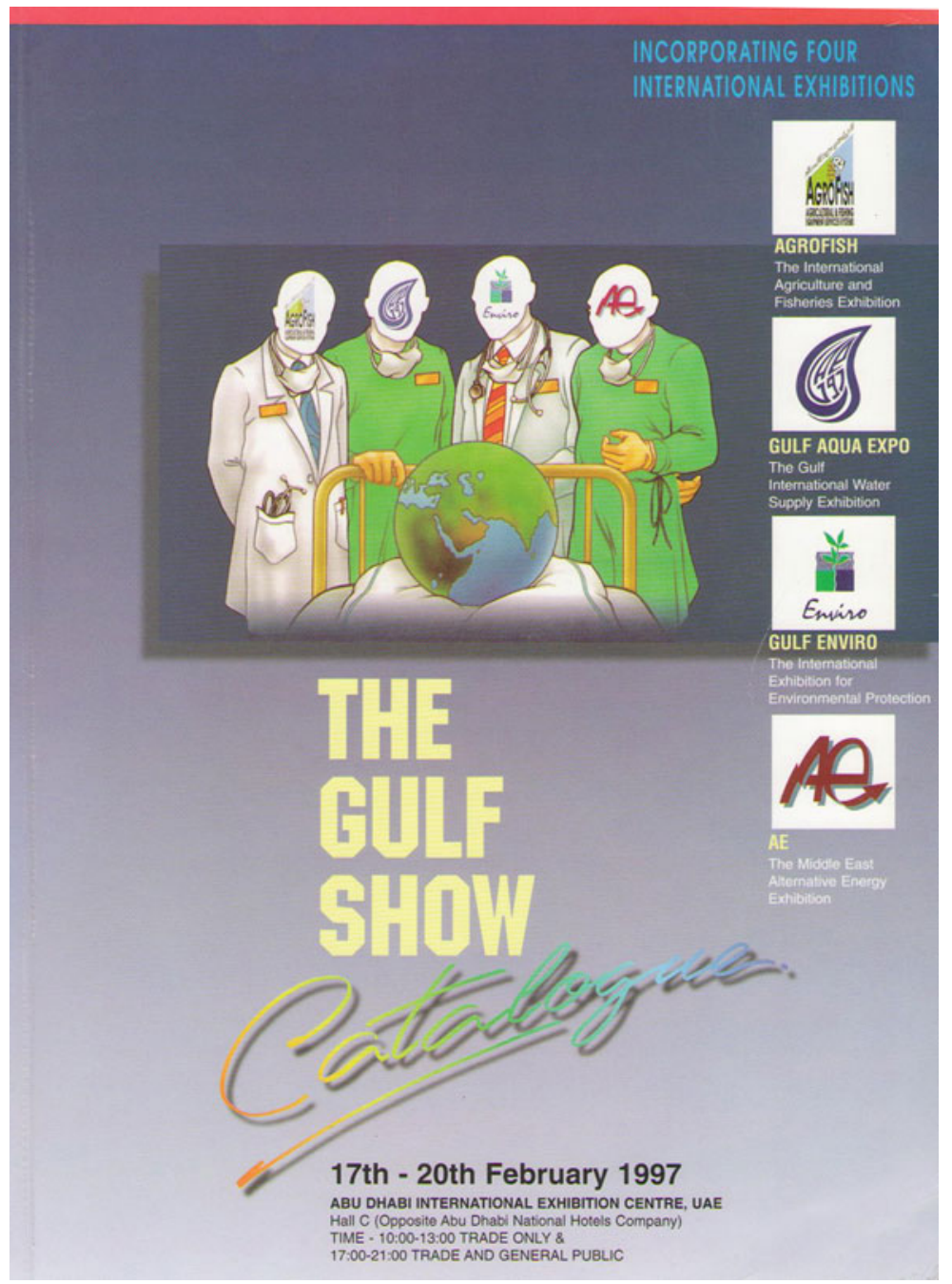

Fig. 79.3 An illustration of ecological modernization in the Gulf. The picture is from a cover of an environmental show and illustrates a sick earth in a hospital bed surrounded by four male doctors curing the earth with modern technology

environmental impact assessments, and many resources are being invested in creating a green image of the projects. Still, I argue, the megaprojects are all based on the continuation of a non-sustainable lifestyle. And this is one of the core issues and mysteries of the discourse on ecological modernization. The discourse successfully hides the conflicts between consumption and ecological concerns. It makes us believe that energy- and resource efficiency is sufficient enough, without questioning the total use of resources, energy or the consumerist lifestyle in total. So can the ecological modernization and megaengineering projects solve the environmental 
problems in the UAE? I have already shown some examples of negative ecological impact of these projects. What interests me is how these projects can be depicted as environmentally beneficiary in the public discourse. I will illustrate some examples.

One example how energy efficiency is mystifying the total use of energy (or in a harsh way of putting it -: the squandering of energy by creating a winter environment in one of the world's hottest climates) is from Ski Dubai. Phil Taylor, engineer in the project says to the Alfa Laval International Customer Magazine (2008) "People would think that Ski Dubai requires huge amounts of energy, but our system is incredibly energy efficient." He continues: "Actually our energy costs are less than $10 \%$ of our operating costs. Right now the wall-mounted chillers installed to maintain the temperature are not even running. The cooling effect of the glycol system and the snow layer as such is enough to maintain the desired temperatures day and night." The article continues enthusiastically: "The energy efficiency goes further than this. Ski Dubai and the Mall of the Emirates are integrated into an extremely efficient energy recovery and recycling system. The 30-40 tonnes (33-44 tons) of snow that are removed every night to make room for the new snow is melted and used in the chilled water supply for the system that air-conditions the mall. After that the water from the melted snow is used to irrigate the gardens. So the energy is actually used three times" (emphasis added). Even though the energy is efficiently used, the whole issue of creating the world's largest refrigerator in the world's hottest climate is not scrutinized critically.

The ecological awareness is present but rather as an image and as management issues. In an article on Masdar, the ecological city, the question is:

But, the United Arab Emirates is an oil-rich nation containing approximately 10 percent of the world's oil reserves. So why is Abu Dhabi doing this? "The answer is simple," says Sultan Al Jaber, CEO of Abu Dhabi Future Energy Co., which is the developer planning the city. "There are two reasons. Number one, because we can. Number two, because we should. And because this is a logical step and a natural extension for our involvement in the energy markets."

In other words, when the oil runs out, which it eventually will, Abu Dhabi wants to be ready to sell the world solar or wind or whatever renewable technologies will be needed to supply people's energy needs. But there's another reason. "Abu Dhabi wanted to show that it's aware of its carbon footprint today," says Khaled Awad, the man in charge of building Masdar City. (Palca, 2008; emphasis mine)

Abu Dhabi, is investing to maintain a leading position in the global energy market. So is this the real reason hidden behind this large scale ecological experiment? Economic concerns have always taken precedence over ecological ones. Or is the whole project just about creating a new green image and getting rid of its bad ecological reputation?

In a panel debate arranged by TreeHugger, the \$US 22 billion project of Masdar was debated from an ecological point of view (Fox, 2008). The expert expressed some ambivalence towards the project. The question was stated:

With entire economies based on selling oil and natural gas to fund massive, rapid growth and a per capita ecological footprint larger than the United States, the United Arab Emirates is currently one of the most unsustainable places in the world. Are Masdar City and the Masdar Initiative a first step toward genuine sustainable development in the Gulf, or a very clever 
strategy to shield the Emirates from environmental criticism while they continue along the same unsustainable path?

Professor Sahar Attia anwered: "Sustainability is among their goals, and they hope to reach it through the Masdar project; but that does not mean that it will be replicated throughout the UAE, especially if it contradicts their current path of growth and development." Richard Register, ecological theorist, stated that:

Sustainable? How could it possibly be? What on Earth could they mean by that? Maybe massive solar energy, once established, could run artificially refrigerated environments on the sun's energy, partially shaded, solar cooled greenhouses producing food, fish farms also run on solar, boats on solar electricity and on and on after massive investments. But the kind of synthetic life there would seem unbearable to anyone who loves natural animals or plants. Very weird.

Professor Peter Droege, chair of the World Council for Renewable Energy concluded by saying: "The only way for Masdar to be $100 \%$ fossil fuel free and sustainable at this late stage in the unfolding climate-tipping-point drama would be to not build it at all, and instead spend the money on converting the rest of the economy and infrastructure onto a renewable footing." This comment could stand as a reminder that ecological modernization makes us dazzled by technological solutions that hide the more obvious questions at stake.

A second example is the other ecological city. OMA, the developers of the new ecological city in Ras al-Khaimah put the obvious "eco riddle" on their homepage: "If green is good ... what is greening of the desert?" They answer themselves: "For some time now desert developments have been constructed as though they could have been constructed anywhere else. Large sections of the desert are being turned into high maintenance lawn. Levels of energy and water consumption are representing immense ecological cost." However, their project will make a difference. They continue: "This project couples the conveniences of one's home to the proximity of cultural and social provisions, the intimacy of the traditional street to smooth accessibility and quality public realm to a large quantum of development.... Concentration, density, synergy, simultaneity, critical mass are the main features, not out of nostalgia, but out of absolute necessity." (OMA, 2008) It is good that urban concentration is addressed, but again large scale lifestyle issues are not addressed.

\subsection{Conclusions}

My conclusion based on the facts presented above is that the creation and evolution of a new environment in the UAE is not sustainable in the broader environmental perspective. The discourse of ecological modernization successfully hides this fact by focusing on new technologies, renewable energy, energy efficiency and environmental impact assessments, but without addressing the non-sustainable lifestyle promoted in this development. The economy of the post-oil era in the UAE somehow presumes that existing lifestyle can be maintained in the future and that fossil fuels can be fully replaced by renewable energy sources. Will it be possible? This is not a question addressed to the UAE only, but a crucial question to the entire 
globe and its inhabitants. The Emiratis have a unique position with its excessive financial means to create whatever future they wish to see. Still, they are vulnerable since their wealth is utterly dependent on business as usual and the continued export of fossil fuels. The discourse of ecological modernization makes us blind to the obvious fact that in order to attain the means to make the emirates ecological, the Emiratis have to sell more oil, with the result that more ecological problems will be created. One has to be aware of that the energy doomsday scenarios sketched in the 1970s are happening here and now, and not there and then.

\subsection{Addendum (February 2009)}

I am not an economist and must rely on secondary sources to speculate on how the global economic crisis has affected the Emirati megaprojects. It is obvious that the global economic recession and the decline in oil price (from \$US 140 dollar per barrel last summer to about \$US 35 in February 2009) have created an abrupt halt in the Gulf economic boom. These economies, as I have argued, are more reliant on fossil fuel exports than they like to admit. Stock and real estate markets have subsequently fallen dramatically. However, the previous good years have provided UAE a buffer to cope with fiscal deficits, even if the GDP would fall in 2009.

A check on the homepages of the megaprojects presented reveals that none of the projects have been cancelled, and even if this was the case, it would probably not been admitted in public yet. It is difficult to know the true status of these enterprises due to reasons of competition and prestige. The cost of construction might have been covered in advanced, but the problems regarding the success and use of these constructions will appear later on. A plausible scenario is ghostly artificial islands, skyscrapers, desert cities and business quarters empty of people.

In this paper I raised the question if these megaprojects could be considered as sustainable. The recent economic recession has really made my point. Overproduction of luxury in the UAE existed even before the crisis a problem, but the demand for luxury properties has now dropped drastically. I criticized the Emirati strategy for developing an economy that is basically dependent on businessas-usual and I think the recent crisis has revealed its vulnerability. I have shown that the Emirati development is not ecologically sustainable, but moreover, the global crisis have shown that is not even economic sustainable or even viable in the longer perspective.

\section{References}

Alfa Laval International Customer Magazine here (No 22, April, 2008). Article by Birgitta Lundblad. Skiing in the desert. Retrieved June 16, 2008, from http://here.alfalaval.com/ ?page ID $=3 \&$ articleID $=894 \&$ keyTechnology $\mathrm{ID}=2$

Burj Dubai Skyscraper. Retrieved September 9, 2008, from http://www.burjdubaiskyscraper.com/ 2005/competitors/alburj.html 
Butler, T. (2005). Dubai's artificial islands have high environmental cost. The price of "The World": Dubai's Artificial Future. Article published on mongabay.com August 23, 2005. Retrieved July 6, 2008, from http://news.mongabay.com/2005/0823-tina_butler_dubai.html

Dubai Properties. Retrieved September 26, 2008, from http://dubai-properties.ae/en/ Projects/BusinessBay/Index.html

Dubai Towers Dubai. Retrieved September 29, 2008, from http://www.dubaitowersdubai.com/.

Dynamic Architecture. Official website of Da Vinci tower. Retrieved September 24, 2008, from http://www.dynamicarchitecture.net/home.html

Eder, K. (1996). The social construction of nature. London: Sage.

Eikongraphia. Retrieved September 25, 2008, from http://www.eikongraphia.com/?p=223

Emaar Properties. Homepage of the constructor/developer of Burj Dubai. Retrieved September 8, 2008, from http://burjdubai.com/MediaCenter/PressReleases/2008September01.asp

Emporis. The World's Website about Buildings. Retrieved September 24, 2008, from http://www.emporis.com/en/wm/bu/?id=271744

Fox, J. (2008). Ecocities of Tomorrow: Can Foster + Partner's Masdar City in U.A.E be Truly Sustainable? Published 03.4.08. Retrieved September 24, 2008, from http://www. treehugger.com/files/2008/03/masdar-roundtable.php

Global Footprint Network. Retrieved September 25, 2008, from http://www.footprintnetwork.org/ gfn_sub.php?content=global_footprint

Gulf News. Dubai Creek link to sea approved. Published April 20, 2007. Retrieved September 26, 2008, from http://archive.gulfnews.com/articles/07/04/20/10119562.html

Hajer, M. A. (1995). The politics of environmental discourse: Ecological modernization and the policy press. Oxford: Clarendon Press.

Heard-Bey, F. (1996 [1982]). From trucial states to United Arab Emirates: A society in transition. London \& New York: Longman.

Heard-Bey, F. (1997). The tribal society of the UAE and its traditional economy. In E. Ghareeb. \& I. Al Abed (Eds.), Perspectives on the United Arab Emirates (pp. 254-272). London: Trident Press.

Jodidio, P. (2007). Architecture in the Emirates. Köln: Taschen.

Long, D. E. (1996 [1978]). The Persian Gulf: An introduction to its peoples, politics, and economics. Boulder: Westview Press.

Luxury Launches. Retrieved September 24, 2008, from http://www.luxurylaunches.com/buildings/ burj_mubarak_alkabir_in_kuwait_will_be_the_tallest_building_in_the_world.php

Nakheel. Developer of the Palm islands. Retrieved September 25, 2008, from http://www.thepalm.ae/

OMA, The Office for Metropolitan Architecture. Retrieved September 25, 2008, from http://www.oma.eu/index.php?option $=$ com_projects\&view $=$ project $\& i d=443 \& I t e m i d=10$

Ouis, P. (2002b). Islamization as a strategy for reconciliation between modernity and tradition: Examples from contemporary Arab Gulf states. Islam and Christian-Muslim Relations, 13(3), $315-334$.

Ouis, P. (2002a). Power, person, and place: Tradition, modernity, and environment in the United Arab Emirates. Lund: Lund Studies in Human Ecology 4, Lund University.

Ouis, P. (2002c). 'Greening the Emirates': The modern construction of nature in the United Arab Emirates. Cultural Geographies, 9, 334-347.

Palca, J. UAE has mixed motivations for eco city. NPR May 5, 2008. Retrieved July 7, 2008, from http://www.npr.org/templates/story/story.php?storyId=90139449

SkyscraperPage Forum. Retrieved September 24, 2008, from http://forum.skyscraperpage.com/ showthread.php?t=135116

State of the Environment Abu Dhabi. Retrieved September 25, 2008, from http://www.soe.ae/Abu_ themespage.aspx? $\mathrm{m}=185$

The Masdar Initiative. Retrieved September 26, 2008, from http://www.masdaruae.com/index.aspx 
Tom Wright. Homepage of the architect behind Burj al-Arab. Retrieved September 8, 2008, from http://www.tomwrightdesign.com/web/burj_al_arab.php

UAE Interact. Retrieved June 18, 2008, from http://www.uaeinteract.com/docs/UAE_presents_ interim_report_on_key_Ecological_Footprint_data/29205.htm

UAE Ministry of Information and Culture. (1993). The UAE 1993. Dubai: Hyatt Annas Magazine.

UAE Ministry of Information and Culture. (1995). The United Arab Emirates. Dubai: Motivate Publishing. 